\title{
Recent Developments in Infectious Disease Chemotherapy: Review for Emergency Department Practitioners 2020
}

\author{
Boris Garber ${ }^{1}$ (D) Jonathan Glauser ${ }^{1}$
}

Published online: 16 June 2020

(C) Springer Science+Business Media, LLC, part of Springer Nature 2020

\begin{abstract}
Purpose of Review We discuss and review new antimicrobials for treatment of bacterial, viral, fungal, and parasitic infections with indications, contraindications, and side effects for each. We will also review new information and indications on older agents that are relevant to clinical practice. Many of them may be unfamiliar to Emergency Physicians given their newness and at times hospital restrictions on their use. We also review some new promising agents that are not yet in the clinical pipeline.

Recent Findings As new antibiotics become available for clinicians to use, new information becomes available with respect to the drugs' indications, efficacy, pathogen resistance, drug-drug interactions, and side effects.

Summary This article provides Emergency Department clinicians with a useful summary with new information on antibiotic use and recent research into agents which may become available.
\end{abstract}

Keywords Antibiotic $\cdot$ Resistance $\cdot$ Emergency $\cdot$ Development

\section{Introduction}

Antibiotics play a critical role in pharmacological management of Emergency Department patients presenting with apparent infectious disease [1]. Antibiotic resistance development is a constant threat whether bacterial, viral, or fungal infections are concerned $[2 \cdot, 3 \bullet \bullet, 4]$. As the new agents emerge and become available for clinical use, some antimicrobials lose effectiveness in some areas, while others become repurposed for a new indication. As multidrug resistant organisms increase in prevalence so is the need for antimicrobial polypharmacy early on in the management of the critically ill infected patients as well as prolonged courses of antibiotics, increasingly done on an outpatient basis $[2 \bullet, 5]$. Whether the Emergency Physician initiates treatment with an antimicrobial or is faced with a patient already taking one, a good understanding of shifting indications and contraindications for their use as well as drug-drug interactions and side effects continues

This article is part of the Topical collection on Infectious Disease

Boris Garber

bgarber@metrohealth.org

1 MetroHealth Medical Center, Case Western Reserve School of Medicine, Cleveland, OH, USA to be important. Thus, staying abreast of new developments in infectious disease pharmaceutical armamentarium is a must for Emergency Medicine providers.

\section{Antibiotic Resistance}

Antibiotic-resistant bacteria continue to spread worldwide and are a persistent and severe health threat [2•] with morbidity and mortality increasing annually [6]. There are multiple implications to physicians caring for patients with presentations concerning for infectious etiology, including the frequent need for early administration of multiple broad-spectrum antibiotics [7]. Emergency Departments (EDs) are a common entry point for care for patients with a range of infectious diseases [3••], and ED physicians are on the front line for early and sometimes the only antibacterial therapy choice for these patients. Patients affected by extended spectrum $\beta$-lactamase-producing and colistin-resistant Pseudomonas aeruginosa, carbapenem-resistant Enterobacteriaceae, methicillinresistant Staphylococcus aureus, and drug-resistant Neisseria gonorrhoeae are encountered routinely in US Emergency Departments [3••]. Multidrug-resistant bacteria are affecting all populations and have been implicated even in neonatal sepsis requiring broader coverage in that patient group [8, 9]. It is important for ED providers to stay abreast of new 
therapies and concepts for these common and serious infections $[3 \cdot \bullet]$.

Antibiotic resistance development is not limited to bacteria; it involves all human pathogens. Pathogenic viruses have been known to become resistant to antivirals, with influenza $\mathrm{A}$ and B now commonly resistant to adamantane compounds and occasionally resistant to newer neuraminidase inhibitors $[4$, 10]. Several antiviral compounds are being currently studied, including favipiravir and fludase with potential broad activity against many pathogenic RNA viruses such as Ebola, West Nile, rabies, and Zika in addition to influenza viruses [10]. Another drug in clinical trials for influenza treatment is the neuraminidase inhibitor laninamivir which would be available as a nasal inhalation if approved [11]. Nitazoxanide, an antiparasitic agent, used to treat cryptosporidium infection in AIDS patients is currently in trials for influenza treatment due to its apparent antiviral activity [11]. Development of a more effective flu vaccine would do much to control influenza epidemics [4]. As far as other viral diseases are concerned, Presatovir (GS-5806) is in trials for Respiratory Syncytial Virus infection [11] and sofosbuvir, a drug previously approved for hepatitis $\mathrm{C}$ treatment, is in trials for treatment of Zika virus infection [12]. While several new compounds are being studied, nothing new has become available for herpes virus illnesses since our last update[13].

Recently, several fungal disease outbreaks have been noted worldwide, ranging from keratitis in contact lens wearers to health care-associated fungal infections with high mortality [14]. Even as both invasive fungal infections and fungal resistance to currently limited antifungal drugs are becoming more common, and there are several molecules being studied for a number of fungal diseases [15], there have not been any new antifungals approved for use in the USA since our last review in 2017. Some strains of Candida glabrata and auris implicated in disseminated disease are now multidrug resistant [16].

The risk factors for infection with antibiotic-resistant bacteria include prior history of such an infection, chronic vascular access or chronic wound, and immunocompromised status stemming from chronic severe illness, malignancy, or primary immunologic defects $[3 \bullet \cdot]$. The need to use broad-spectrum antibiotics liberally and early unfortunately contributes to constantly emerging and evolving patterns of pathogen resistance $[9,17]$. Meanwhile, it has become a routine to use antibiotics liberally in situations where previously they were used infrequently, such as in patients with simple skin abscesses [18].

Several pathogens were recently identified by the World Health Organization (WHO) as a critical priority, based on mortality, health care burden, and prevalence of resistance $[1,7]$ (Table 1 ). The only two new antibacterial classes to be approved in the past 20 years-lipopeptides and oxazolidinones - are active against gram-positive pathogens [1]. Quinolones, which first appeared in 1960, was the last novel class of antibiotics discovered to be active against
Table 1 Critical priority bacteria according to WHO $[1,2 \bullet]$

gram-negative bacteria [1]. Unfortunately many large pharmaceutical companies have limited investment into research in the past decade to discover new antibiotics in part due to negative financial incentives [19]. By definition, antimicrobials are meant in general to cure disease rather than to be taken forever as, for example, medications to treat diabetes or hypertension. Furthermore, antimicrobial husbandry includes attempts to limit pathogen resistance by limiting the time course of treatment. Additionally, the FDA requires that new agents for use in simple infections show superiority, which would require a very large number of subjects enrolled in a study, since most of these infections resolve spontaneously [19].

Infections caused by resistant bacteria cause up to two-fold increase in adverse outcomes, even when the pathogen remains susceptible to the antibiotic but a higher minimal inhibitory concentration (MIC) is present [20•], especially if septic shock develops [21]. This contributes to the need to use antibiotics in higher doses and for longer courses. There is evidence that even $\beta$-lactams in high concentrations can produce a range of organ toxicity especially in the critically ill, including neurologic, hepatic, renal, and hematological side effects whose frequency may be currently underestimated [22]. Cephalosporins, including novel ones, appear to be proconvulsive, especially in patients with epilepsy [22]. Not only are resistant bacteria more difficult to control in case of infection, but surgical antibiotic prophylaxis has also become less effective, as evidenced for example by an increase in bacteremia after invasive urological procedures despite fluoroquinolone prophylaxis [20•]. This is an important point to keep in mind for Emergency Department doctors when these patients present.

Other important mechanisms for development and spread of resistant bacteria have been recently emphasized. For example, many bacteria and fungi have the ability to form biofilms by both free living and pathogenic species, thereby limiting local antibiotic penetration [5]. Chronic infection in rhinosinusitis, purulent ulcers, and cystic fibrosis seem to be due to biofilms in large part [2•]. As another example, 

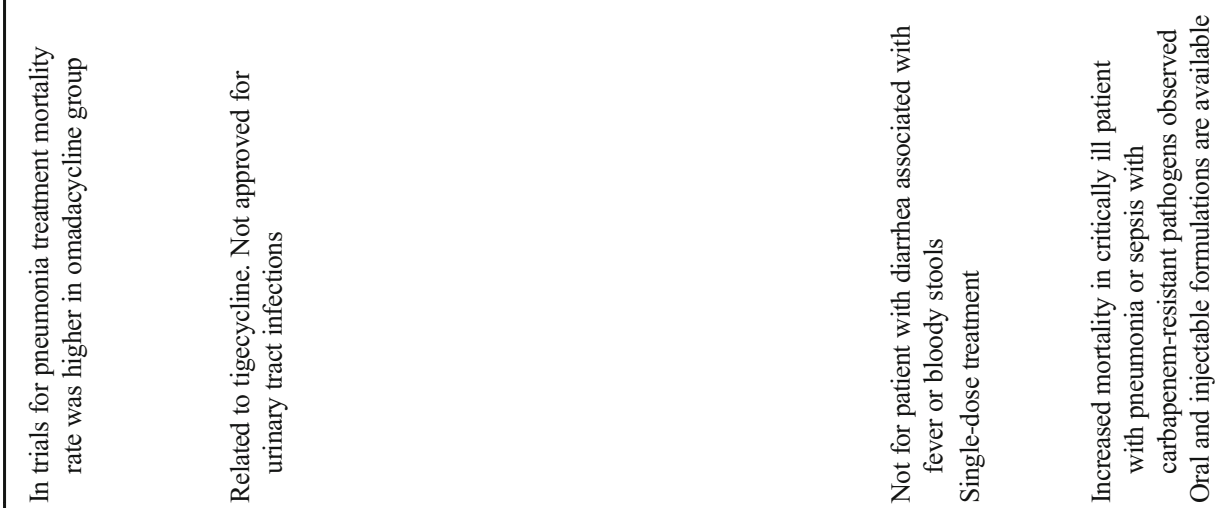

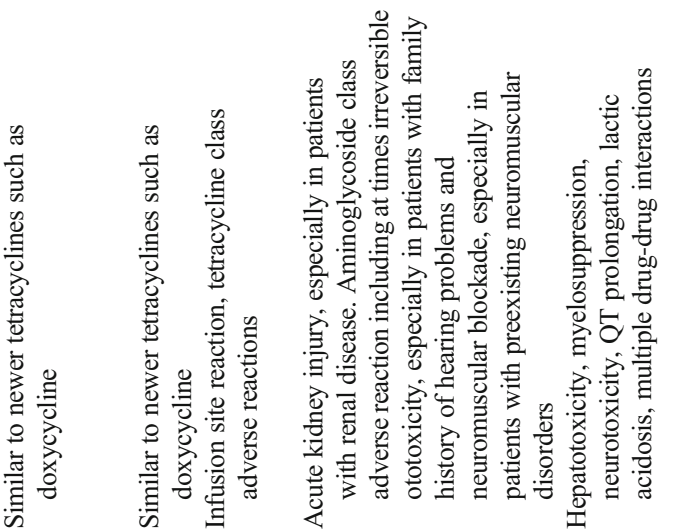
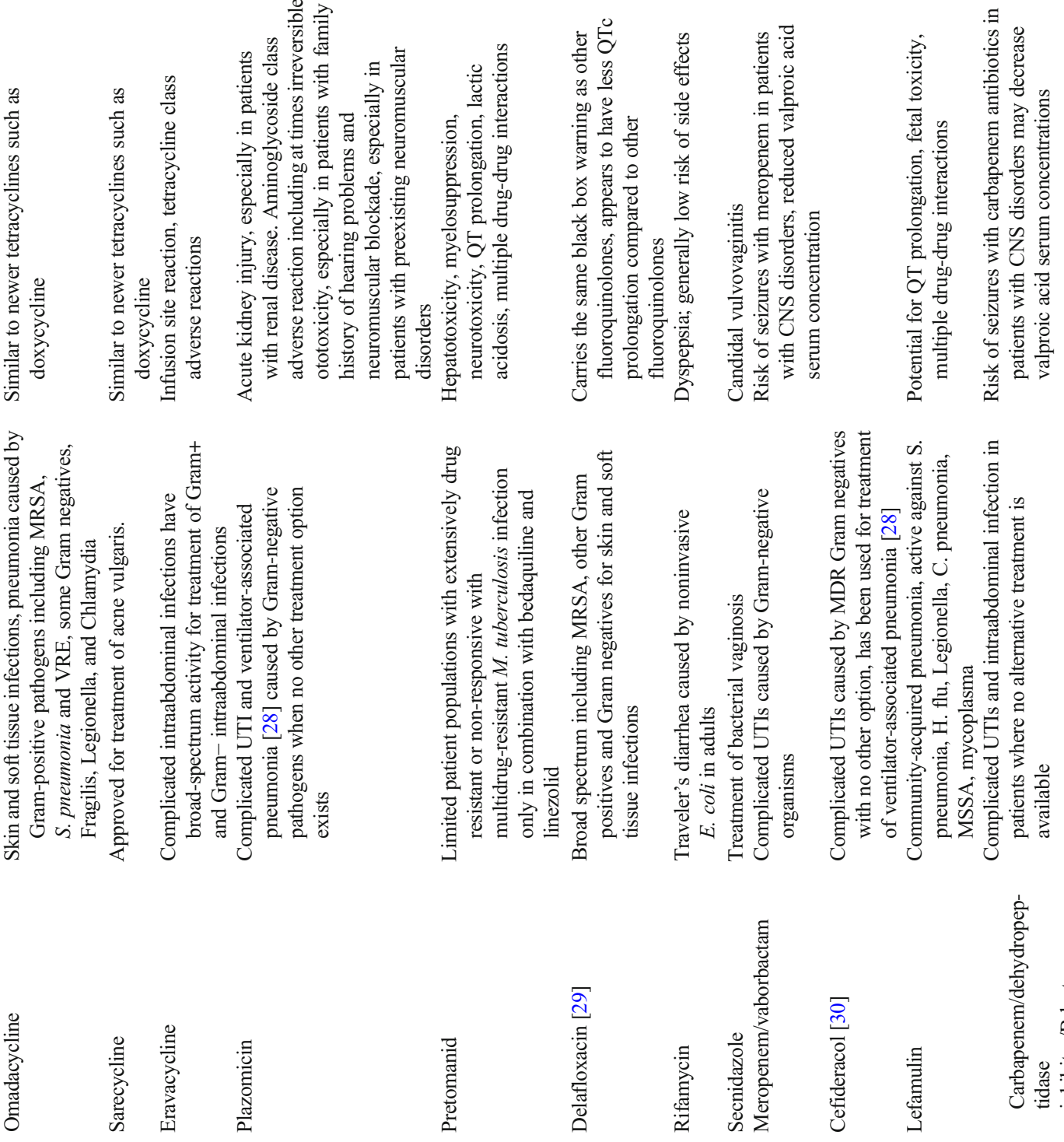

믈
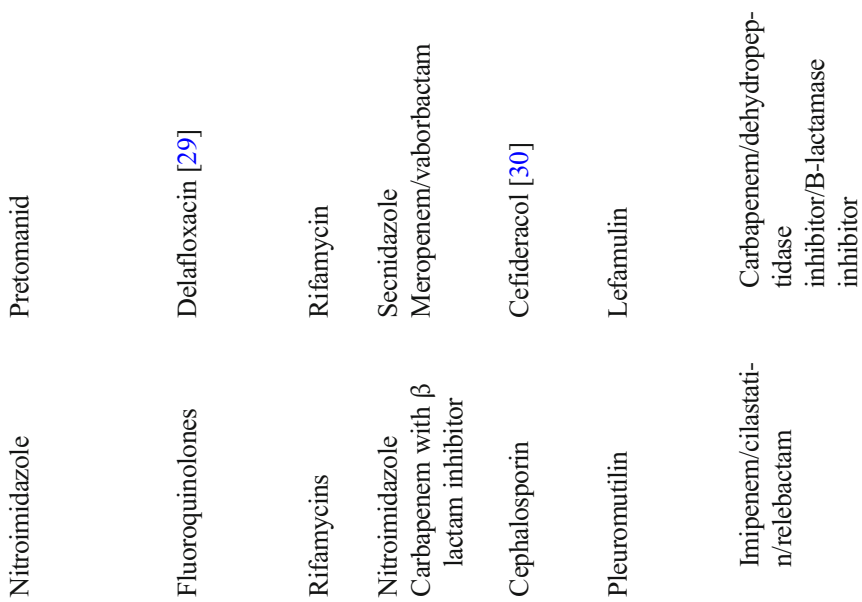
Table 3 Select new FDA-approved anti-tuberculosis drugs and antivirals on the market in the USA since year 2017

\begin{tabular}{|c|c|c|c|c|}
\hline Drug class & Names and notes & Indications & Side effects & Comments \\
\hline $\begin{array}{l}\text { Antiviral protein } \\
\text { inhibitor }\end{array}$ & Tecovirimat & $\begin{array}{l}\text { Small pox in adults and } \\
\text { children }\end{array}$ & $\begin{array}{l}\text { Headache in healthy volunteers; } \\
\text { hypoglycemia when combined } \\
\text { with repaglinide }\end{array}$ & $\begin{array}{l}\text { Available through Strategic } \\
\text { national Stockpile. } \\
\text { Unknown efficacy in } \\
\text { humans }\end{array}$ \\
\hline $\begin{array}{l}\text { Endonuclease } \\
\text { inhibitor }\end{array}$ & Baloxavir marboxil & $\begin{array}{l}\text { Influenza up to } 48 \mathrm{~h} \text { in } \\
\text { duration in patients } \\
12 \text { years of age or older }\end{array}$ & $\begin{array}{l}\text { No significant side effects } \\
\text { described }\end{array}$ & $\begin{array}{l}\text { Single-dose completes the } \\
\text { course of treatment, avoid } \\
\text { co administration with } \\
\text { antacids, laxatives, or oral } \\
\text { supplements }\end{array}$ \\
\hline $\begin{array}{l}\text { Non-nucleoside } \\
\text { reverse transcriptase } \\
\text { inhibitor }\end{array}$ & Doravirine & $\begin{array}{l}\text { Combination therapy } \\
\text { for HIV infection }\end{array}$ & $\begin{array}{l}\text { Uncommon; immune } \\
\text { reconstitution inflammatory } \\
\text { syndrome }\end{array}$ & $\begin{array}{l}\text { Do not co-administer strong } \\
\text { cytochrome P450 enzyme } \\
\text { inducers }\end{array}$ \\
\hline $\begin{array}{l}\text { Monoclonal anti MDR } \\
\text { HIV antibody }\end{array}$ & Ibalizumab-uiyk & MDR HIV infection & $\begin{array}{l}\text { Diarrhea, rash; immune } \\
\text { reconstitution inflammatory } \\
\text { syndrome }\end{array}$ & \\
\hline $\begin{array}{l}\text { Anti-hepatitis C } \\
\text { combination drug }\end{array}$ & $\begin{array}{l}\text { Glecaprevir and } \\
\text { pibrentasvir }\end{array}$ & Hepatitis C infection & $\begin{array}{l}\text { Reactivation of hepatitis B that } \\
\text { can result in fulminant } \\
\text { hepatitis; worsening liver } \\
\text { failure; }\end{array}$ & $\begin{array}{l}\text { Contraindicated in patients } \\
\text { with severe liver } \\
\text { impairment; avoid } \\
\text { co-administering strong } \\
\text { cytochrome P450 enzyme } \\
\text { inducers }\end{array}$ \\
\hline $\begin{array}{l}\text { Anti-hepatitis } \mathrm{C} \\
\text { combination drug }\end{array}$ & $\begin{array}{l}\text { Sofosbuvir/velpatas- } \\
\text { vir/voxilaprevir }\end{array}$ & Hepatitis C infection & $\begin{array}{l}\text { Reactivation of hepatitis B that } \\
\text { can result in fulminant } \\
\text { hepatitis, case reports of severe } \\
\text { bradycardia when amiodarone } \\
\text { is co-administered; headache }\end{array}$ & $\begin{array}{l}\text { Not recommended in } \\
\text { patients with moderate to } \\
\text { severe hepatic } \\
\text { impairment; do not co } \\
\text { administer rifampin; }\end{array}$ \\
\hline
\end{tabular}

Pseudomonas aeruginosa resistance to fluoroquinolones may be induced by diltiazem, a commonly used calcium channel blocker $[2 \cdot]$.

Even when an antibiotic is withdrawn, or its use restricted, it does not guarantee that a bacterium will become susceptible to it again. Multidrug-resistant traits do not affect Gonorrhea biological fitness, so it persists despite the lack of antibiotic exposure selection pressure [23].

Broad-spectrum antibiotic use puts patients at risk for developing Clostridium difficile colitis (CDI). A recent Cochrane review emphasized increased symptomatic cure with vancomycin when compared to metronidazole,

Table 4 Select new indications for old antibiotics [23, 31]

\begin{tabular}{|c|c|c|}
\hline Name & Explored new indications & Comments \\
\hline Gentamicin, kanamycin & N. gonorrhoeae infections & \\
\hline Ertapenem & N. gonorrhoeae infections & \\
\hline Fosfomycin & N. gonorrhoeae infections & \\
\hline Spectinomycin & N. gonorrhoeae infections & $\begin{array}{l}\text { First developed in 1960, abandoned after resistance } \\
\text { emerged and new agents appeared, used again in } \\
\text { some European countries, China, and South Korea } \\
\text { [23] }\end{array}$ \\
\hline Ramoplanin & Clostridium difficile & Not absorbed from oral administration \\
\hline Minocycline & MRSA & \\
\hline Mecillinam [32] & MDR Enterobacteriaceae & Not available in the USA \\
\hline $\begin{array}{l}\text { Tetracyclines, } \beta \text {-lactams, } \\
\text { microcyclics }\end{array}$ & Neuroprotection in Parkinson's disease [33] & Exploring anti-inflammatory properties \\
\hline $\begin{array}{l}\text { Nebulized antibiotics } \\
\text { formulations }\end{array}$ & $\begin{array}{l}\text { Amikacin, ciprofloxacin for ventilator-associated } \\
\text { pneumonia [28] }\end{array}$ & $\begin{array}{l}\text { Currently only colistin, aztreonam, and tobramycin } \\
\text { improved for use exclusively in patients with cystic } \\
\text { fibrosis }\end{array}$ \\
\hline
\end{tabular}


Table 5 Select novel antibiotics in development [23, 31, 34] Google Scholar search

\begin{tabular}{|c|c|c|c|}
\hline Drug class & Names and notes & Indications & Comments \\
\hline Defensins [5] & Brilacidin & Broad-spectrum antibacterial activity & \\
\hline $\begin{array}{l}\text { Medicinal leech and other animal } \\
\text { venom as source for antimicrobial } \\
\text { peptides }[35,36]\end{array}$ & Several peptides are studied & & $\begin{array}{l}\text { Interest based on ability of leech to } \\
\text { store blood for a long time }\end{array}$ \\
\hline $\begin{array}{l}\text { Extremophile bacteria as sources } \\
\text { of antibiotics }[36,37]\end{array}$ & & & $\begin{array}{l}\text { Fusaricidin B isolated from hot } \\
\text { spring-derived bacteria is } \\
\text { assigned a new application } \\
\text { for tuberculosis treatment }\end{array}$ \\
\hline Fluoroketolides & Solithromycin [23] & $\begin{array}{l}\text { Activity against } N \text {. gonorrhoeae, } \\
\text { C. trachomatis, } M \text {. genitalium, } \\
\text { and Gram-positive respiratory } \\
\text { pathogens }\end{array}$ & \\
\hline $\begin{array}{l}\text { Spiropyrimidinetrione } \\
\text { topoisomerase II inhibitor }\end{array}$ & Zoliflodacin & $\begin{array}{l}\text { Activity against XDR } \\
\quad \text { N. gonorrhoeae and C. trachomatis }\end{array}$ & \\
\hline Triazaacenaphthylenes & Gepotidacin & $\begin{array}{l}\text { Activity against MRSA, ESBL } \\
\text { Enterobacteriaceae, and } N . \text { gonorrhoeae }\end{array}$ & \\
\hline $\begin{array}{l}\text { Cephalosporin/vancomycin } \\
\text { heterodimer }\end{array}$ & Cefilavancin & Gram-positive pathogens & \\
\hline Ethambutol & SQ 109 & M. tuberculosis & \\
\hline $\begin{array}{l}\text { Non-absorbable small } \\
\text { molecule antibiotic }\end{array}$ & Ridinilazole & Clostridium difficile all strains & Granted fast track status by FDA \\
\hline Polymixins [38] & NAB741, CB-182804 & Gram negatives & Early stages \\
\hline Peptidomimetic & Murepavadin $[28,39]$ & P. aeruginosa infections & $\begin{array}{l}\text { Novel mechanism of action } \\
\text { pseudomonas specific }\end{array}$ \\
\hline Carbapenems & Tebipenem [40] & Broad spectrum & $\begin{array}{l}\text { First carbapenem with oral } \\
\text { formulation available }\end{array}$ \\
\hline Fluoroquinolones & Nemonoxacin; zabofloxacin & $\begin{array}{l}\text { Broad spectrum with anti } \\
\text { MRSA activity }\end{array}$ & $\begin{array}{l}\text { Approved and used in several } \\
\text { countries }\end{array}$ \\
\hline Boronic acids & RPX7009 [41] & & B-Lactamase inhibitors \\
\hline
\end{tabular}

fidaxomicin compared to vancomycin, and possibly teicoplanin compared to vancomycin [24] in CDI patients. Importantly, no recent studies looked at optimal treatment of severe $C$. difficile colitis [24].

\section{Conclusion}

Even though many clinicians are alarmed at the slow and uneven pace of the new antibiotics development [2•, 20•], a good many antimicrobial agents are now on the market (Table 2) as well as new anti-tuberculosis and antiviral medications (Table 3) since our last paper was published. Opening up new indications for old antibiotics becomes an increasingly important topic (Table 4) with a few stories of success over the years - anti-community MRSA armamentarium includes doxycycline and trimethoprim-sulfamethoxazole, while the new research focuses on testing old antibiotics for Neisseria gonorrhoeae treatment and using anti-inflammatory properties of antibiotics in treatment of progressive degenerative neurological disorders. Several promising molecules are undergoing trials to establish their efficacy as therapeutic agents
(Table 5). Unfortunately, if the history is any guide, only select few will become available for use for an Emergency Physician any time soon $[2 \bullet, 19]$.

Acknowledgments The authors wish to thank Dr. David Effron for reviewing their manuscript.

\section{References}

Papers of particular interest, published recently, have been highlighted as:

- Of importance

-• Of major importance

1. Tacconelli E, Carrara E, Savoldi A, et al. Discovery, research, and development of new antibiotics: the WHO priority list of antibioticresistant bacteria and tuberculosis. Lancet Infect Dis. 2018;18(3): 318-27.

2. Frieri M, Kumar K, Boutin A. Antibiotic resistance. J Infect Public Health. 2017;10(4):369-78. Discusses new recently described mechanisms of pathogen's developing resistance.

3.• Mazer-Amirshahi M, Pourmand A, May L. Newly approved antibiotics and antibiotics reserved for resistant infections: implications 
for emergency medicine. Am J Emerg Med. 2017;35(1):154-8. Good review for the role of some new antimicrobials in the Emergency Department.

4. Hussain M, Galvin HD, Haw TY, et al. Drug resistance in influenza A virus: the epidemiology and management. Infect Drug Resist. 2017;10:121-34

5. Banin E, Hughes D, Kuipers OP. Editorial: Bacterial pathogens, antibiotics and antibiotic resistance. FEMS Microbiol Rev. 2017;41(3):450-2.

6. Burnham JP, Olsen MA, Kollef MH. Re-estimating annual deaths due to multidrug-resistant organism infections. Infect Control Hosp Epidemiol. 2019;40(1):112-3.

7. Pourmand A, Mazer-Amirshahi M, Jasani G. Emerging trends in antibiotic resistance: implications for emergency medicine. Am J Emerg Med. 2017;35(8):1172-6.

8. Shane AL, Sánchez PJ, Stoll BJ. Neonatal sepsis. Lancet. 2017;390(10104):1770-80.

9. Walker O, Kenny CB, Goel N. Neonatal sepsis. Paediatr Child Health. 2019;29(6):263-8.

10. Koszalka P, Tilmanis D, Hurt AC. Influenza antivirals currently in late-phase clinical trial. Influenza Other Respir Viruses. 2017;11: 240-6.

11. Ison MG. Antiviral treatments. Clin Chest Med. 2017;38(1):13953.

12. Fangman Chen Hao Xu Jinli Liu etc Efficacy and safety of nucleoside antiviral drugs for treatment of recurrent herpes labialis: a systematic review and meta-analysis J Oral Pathol Med 2017;46: 561-568

13. Kristen M, Bullard-Feibelman, Jennifer Govero, ZheZhu etc The FDA-approved drug sofosbuvir inhibits Zika virus infection Antiviral Research Vol. 137. 2017;137:134-140

14. Benedict K, Richardson M, Vallabhaneni S. Emerging issues, challenges, and changing epidemiology of fungal disease outbreaks. Lancet Infect Dis. 2017;17(12):403-11.

15. Campoy S, Adrio JL. Antifungals. Biochem Pharmacol. 2017;133: 86-96.

16. Perlin DS, Rautemaa-Richardson R, Alastruey-Izquierdo A. The global problem of antifungal resistance: prevalence, mechanisms, and management. Lancet Infect Dis. 2017;17(12):383-92.

17. Kawasaki T. Update on pediatric sepsis: a review. J Intensive Care. 2017:5:47.

18. Gottlieb M, DeMott JM, Hallock M. Systemic antibiotics for the treatment of skin and soft tissue abscesses: a systematic review and meta-analysis. Ann Emerg Med. 2019;73(1):8-16.

19. Fernandes P, Martens E. Antibiotics in late clinical development. Biochem Pharmacol. 2017;133:152-63.

20. Friedman ND, Temkin E, Carmeli Y. The negative impact of antibiotic resistance. Clin Microbiol Infect. 2016;22(5):416-22. Highlights some unexpected risks of antibiotic resistance.

21. Dupont J, Prat D, Sztrymf B. Linezolid versus vancomycin in Methicillin Resistant Staphylococcus aureus nosocomial pneumonia in the elderly. Am J Emerg Med. 2017;35(8):1197-8.

22. Imani $\mathrm{S}$, Buscher $\mathrm{H}$, Marriott $\mathrm{D}$, et al. Too much of a good thing: a retrospective study of $\beta$-lactam concentration-toxicity relationships. J Antimicrob Chemother. 2017;72(10):2891-7.

23. Alirol E, Wi TE, Bala M, Bazzo ML, Chen X-S, Deal C, et al. Multidrug-resistant gonorrhea: a research and development roadmap to discover new medicines. PLoS Med. 2017;14(7): e1002366.

24. Nelson RL, Suda KJ, Evans CT. Antibiotic treatment for Clostridium difficile-associated diarrhoea in adults. Cochrane Database Syst Rev. 2017;(3).

25. Butler MS, Blaskovich MAT, Cooper MA. Antibiotics in the clinical pipeline at the end of 2015. J Antibiot. 2017;70:3-24.

26. Abbas M, Paul M, Huttner A. New and improved? a review of novel antibiotics for Gram-positive bacteria. Clin Microbiol Infect. 2017;23(10):697-703.

27. David MZ, Dryden M, Gottlieb T, et al. Recently approved antibacterials for methicillin-resistant Staphylococcus aureus (MRSA) and other Gram-positive pathogens: the shock of the new. Int J Antimicrob Agents. 2017;50(3):303-7.

28. Bassetti M, Vena A, Castaldo N. New antibiotics for ventilatorassociated pneumonia. Curr Opin Infect Dis. 2018;31(2):177-86.

29. Ocheretyaner ER, et al. Delafloxacin: a novel fluoroquinolone with activity against methicillin-resistant Staphylococcus aureus (MRSA) and Pseudomonas aeruginosa. Expert Rev Anti-Infect Ther. 2018;16(7):523-30.

30. Choi JJ, et al. Cefiderocol: a novel siderophore cephalosporin. Expert Opin Investig Drugs. 2018;27(2):193-7.

31. Bassères E, Endres BT, Dotson K, et al. Novel antibiotics in development to treat Clostridium difficile infection. Curr Opin Gastroenterol. 2017;33(1):1-7.

32. Zayyad H, Eliakim-Raz N, Leibovici L, Paul M. Revival of old antibiotics: needs, the state of evidence and expectations. Int $\mathrm{J}$ Antimicrob Agents. 2017;49(5):536-41.

33. Reglodi D, Renaud J, Tamas A. Novel tactics for neuroprotection in Parkinson's disease: role of antibiotics, polyphenols and neuropeptides. Prog Neurobiol. 2017:155:120-48.

34. Mishra B, Reiling S, Zarena D, et al. Host defense antimicrobial peptides as antibiotics: design and application strategies. Curr Opin Chem Biol. 2017;38:87-96.

35. Grafskaia EN, Nadezhdin KD, Talyzina IA, et al. Medicinal leech antimicrobial peptides lacking toxicity represent a promising alternative strategy to combat antibiotic-resistant pathogens. Eur J Med Chem. 2019;180:143-53.

36. Demain AL, Gómez-Ortiz B, Ruiz-Villafán B, et al. Recent findings of molecules with anti-infective activity: screening of nonconventional sources. Curr Opin Pharmacol. 2019;48:40-7.

37. Mahajan GB, Balachandran L. Sources of antibiotics: hot springs. Biochem Pharmacol. 2017;134:35-41.

38. Brown P, Dawson MJ. Development of new polymyxin derivatives for multi-drug resistant Gram-negative infections. J Antibiot. 2017;70:386-94.

39. Martin-Loeches I, Dale GE, Torres A. Murepavadin: a new antibiotic class in the pipeline. Expert Rev Anti-Infect Ther. 2018;16(4): 259-68.

40. Jain A, Utley L, Parr TR, Zabawa T, Pucci MJ. Tebipenem, the first oral carbapenem antibiotic. Expert Rev Anti-Infect Ther. 2018;16(7):513-22.

41. González-Bello C. Recently developed synthetic compounds with anti-infective activity. Curr Opin Pharmacol. 2019;48:17-23.

Publisher's Note Springer Nature remains neutral with regard to jurisdictional claims in published maps and institutional affiliations. 